\title{
Ecological Mapping for the Development of Salt Production Centres in Indonesia during the Dutch Colonial Era
}

\author{
M. Zaki Mahasin ${ }^{1 *}$, Yety Rochwulaningsih, and Singgih Tri Sulistiyono ${ }^{l}$ \\ ${ }^{1}$ Doctoral Program of History, Faculty of Humanities, University of Diponegoro, Semarang, \\ Indonesia.
}

\begin{abstract}
This paper examines why the Dutch colonial government did ecological mapping for the development of salt centres in Indonesia and how it was carried out? It is analysed by historical method which includes heuristics, criticism, interpretation and historiography. Ecological mapping was carried out by the Dutch colonial government for the development of salt production centre sourced from sea water. It is the important factor to develop salt production centres concerning the situations of the coastal area in which sloping parallel to sea level, humid, dry air temperatures, low rainfall, non-porous soil types, and high wind speeds. The wind speed required for salt production is at least $5 \mathrm{~m} / \mathrm{sec}$, with air temperatures above $32^{\circ} \mathrm{C}$ during the day, as well as a maximum humidity of $50 \%$. During the Dutch colonial government, it was recorded that in 1904-1917 the average wind speed was above $5 \mathrm{~m} / \mathrm{sec}$. Continued with the development of the salt production ecosystem, which includes the establishment of production areas equipped with bozem development, land layout, etc. By the ecological mapping, the salt development centre areas cover coastal area of Madura, several areas of Java's north coast, and coastal areas of Sulawesi, including Jeneponto.
\end{abstract}

\section{Introduction}

Coastal communities generally know how to make salt. People in Maluku islands pour seawater into a fire on the beach, then boil the ashes with seawater [1]. Coastal areas with a long dry season are ecologically able to produce salt by the evaporation method or sun evaporation in shallow patches of salt pond land. Along the north coast of East Java are patches of salt, which is one of the main exports from the ports between Juwana and Surabaya. Salt-making on the north coast of Java is more straightforward when compared to salt-making techniques on the coast of Bengali, India [2].

Salt production in Indonesia is generally carried out by the method of evaporation of seawater. This method is applied, taking into account the geographical and climatic conditions in Indonesia. Therefore, not all coastal areas in Indonesia have the potential to become centres of salt production. Some of the main factors that make an area suitable for

\footnotetext{
* Corresponding author: zaki_dkp@yahoo.com
} 
salt production are rainfall, soil texture, land contours and access to seawater sources [3]. Other factors include wind speed, air temperature, humidity and sunshine duration [4].

This ecological mapping was part of the colonial government's strategy to project salt production and development areas in the Dutch East Indies. However, the Dutch colonial government was a very effective administrator and, according to Geertz, did not commit to any economic development for its colonies [5]; most of the salt centres that are currently still producing emerged through the concept of ecological development during the colonial period.

At least three studies have analyzed the ecological conditions of salt production centres in Indonesia. Mahasin et al. [3] analyzed the ecological conditions of salt-producing areas in Indonesia. They identified factors that specifically accompany them, such as rainfall, soil texture and contours, and access to seawater. However, this study only focuses on the existing state of salt production centres without tracing the historical roots of this land tenure system. Another study conducted by Yani et al. [6] emphasizes the dependence of salt farmers in Jeneponto on ecological factors, such as uneven rainfall and salt pond conditions. This study also informs that there needs to be support from policyholders to increase production capacity. In addition, Wisnu et al. [7] emphasized that the policy of strengthening the salt business during the colonial period, including the land management system, led to efforts to strengthen the government's position in the global export industry. This study also informs that the salt land management system works with traditional rulers. The study also concluded that the control system for salt land during the Dutch and British colonial governments had similarities. Both the British and Dutch Colonial Governments appointed superintendents and officials under them to oversee the productivity of the salt production centres. They are traditional rulers who had been trusted and had good relations with the government.

Based on the objective conditions and existing studies, this study focuses on mapping ecological conditions to boost salt productivity during the colonial period. The problem that arose in this study was the significance of land mapping efforts with salt productivity in that period. Through this study, information on the factors generally associated with the mapping of salt production centres, namely climatological conditions, in this case, rainfall is the main determining factor for salt production and land contours.

\section{Method}

This study is structured using the historical method, consisting of four stages, heuristics, criticism, interpretation, and historiography. In the context of sourcing, this study uses primary sources in the form of statistical reports in the form of Jaarcijfers Voor het Koninkrijk der Nederlanden 1908-1920. The reports detailed the ecological and climatological conditions of the salt-producing centres during the colonial period. Meanwhile, to analyze as well as answer the problem, a socio-ecological approach was used that emphasizes ecosystem management to support community resilience [8] to natural disturbances that occurred [9]. 


\section{Results and Discussion}

\subsection{Factors in Salt Production}

In general, the salt production method in Indonesia involves the evaporation of seawater in shallow pools by taking into account the viscosity of seawater in these pools. The production process emphasizing the evaporation method in shallow water pools to accelerate the evaporation process has been practised in Madura since the Dutch colonial period [10].

Salt production before 1882 was not based on measurable evaporation techniques. At that time, salt production was still carried out traditionally. On Madura Island, salt production was only carried out on the south coast because the salt content of seawater was higher than that on the north coast. The condition of the south coast, which is affected by the dry wind, called gending, originates from the mountains passing through Probolinggo Regency, causing the salt crystallization process to be faster.

The method of salt production was quite simple. Quarter bau plots (the unit for measuring land area, one bau has an area of about 7,000 square meters) were prepared first, and then seawater was channelled through the canals. Pathways were built between the plots to facilitate the harvesting of the salt crystals. Production preparation preceded by land improvement started in April, and usually, production started in May. The evaporation period for one harvest was 25-28 days, after which the salt was ready to be harvested and then transferred to another place that was drier and cleaner. The final drying was done by drying the salt for 4-10 days in the hot sun and aerated. At night, the salt was protected from rainwater with kajang or alang-alang leaves.

At the same time, after the plots had been cleared of salt residue, the plots were again flooded with seawater to start production again, and so on. At the end of September, the third crop and the salt season were over. The salt plots were then turned into fish ponds or left alone. These salt plots were often damaged during the rainy season and required many repairs before being used again in the following year's salt season [11].

\subsection{Mapping of Production Locations}

In general, the mapping of salt fields uses a rainfall reference. The required rainfall in coastal areas should not be more than $60 \mathrm{~mm}$ per month in the dry season. Rain like this is not found in all coastal regions of Indonesia. Rainfall patterns that are suitable for salt production have a clear boundary between the rainy season and the dry season, as happened in the areas of Java, Madura, Nusa Tenggara and parts of Sulawesi, which have the monsoonal rainfall type [3]. Rainfall data in 1940 [12] as shown in Table 1.

Table 1. Rainfall at Selected Locations, $1940(\mathrm{~mm})$

\begin{tabular}{|c|c|c|c|c|c|c|c|c|c|c|c|c|c|}
\hline Location & Е & 过 & $\tilde{\pi}^{\tilde{\pi}}$ & $\dot{\vec{\alpha}}$ & 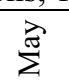 & $\Xi$ & $\Xi$ & $\stackrel{200}{Z}$ & $\stackrel{\otimes}{\mathscr{D}}$ & $\overrightarrow{0}$ & zo & 若 & 苛 \\
\hline Jakarta & 713 & 269 & 186 & 135 & 170 & 53 & 19 & 12 & 6 & 3 & 43 & 186 & 1.795 \\
\hline Bandung & 66 & 60 & 439 & 163 & 214 & 162 & 60 & 70 & 12 & 28 & 244 & 378 & 1.896 \\
\hline Semarang & 567 & 224 & 195 & 132 & 138 & 47 & 5 & 83 & 1 & 176 & 124 & 245 & 1.937 \\
\hline Surabaya & 410 & 194 & 344 & 185 & 37 & 6 & 2 & 0 & 0 & 0 & 17 & 316 & 1.511 \\
\hline Medan & 41 & 34 & 41 & 69 & 124 & 131 & 132 & 203 & 359 & 391 & 105 & 327 & 1.957 \\
\hline
\end{tabular}




\begin{tabular}{lccccccccccccc} 
Padang & 279 & 157 & 457 & 215 & 372 & 306 & 192 & 284 & 303 & 417 & 545 & 498 & 4.025 \\
Palembang & 179 & 283 & 230 & 198 & 191 & 91 & 94 & 103 & 28 & 58 & 193 & 221 & 1.869 \\
Pontianak & 165 & 191 & 139 & 152 & 171 & 142 & 25 & 25 & 130 & 205 & 173 & 215 & 1.733 \\
Balikpapan & 245 & 186 & 288 & 180 & 567 & 299 & 235 & 211 & 80 & 21 & 166 & 197 & 2.675 \\
Manado & 433 & 426 & 248 & 104 & 228 & 60 & 25 & 97 & 0 & 10 & 90 & 267 & 1.983 \\
Makassar & 1.315 & 687 & 318 & 227 & 109 & 18 & 0 & 0 & 0 & 0 & 66 & 482 & 3.222 \\
Ambon & 140 & 91 & 168 & 172 & 1.068 & 404 & 125 & 152 & 47 & 72 & 11 & 30 & 2.480 \\
Kupang & 395 & 259 & 272 & 50 & 0 & 0 & 1 & 0 & 0 & 0 & 12 & 210 & 1.199 \\
\hline
\end{tabular}

Table 1 shows that salt production in Indonesia is generally very much influenced by rainfall. In areas with rainfall within a certain timeframe below $60 \mathrm{~mm} / \mathrm{month}$ can be used as a location for salt production if the area has beaches and easy geographic access. The north coast of Java Island, Madura Island, Sulawesi Island, and Kupang are generally suitable for salt production. In this region, there are at least 3-5 months of rainfall below $60 \mathrm{~mm} / \mathrm{month}$ during the dry season and some even up to $0 \mathrm{~mm} / \mathrm{month}$. Especially for Kupang, this condition lasted for eight months. In the western part of Gresik, namely, Lamongan also has geographic conditions that prove suitable for producing salt [13]. Rainfall in salt production is a major factor. This can be seen in Figure 1, which shows the correlation between rainfall and salt production (in thousands of tons) in 1936-1940, that the higher the rainfall, the less production will be and vice versa.

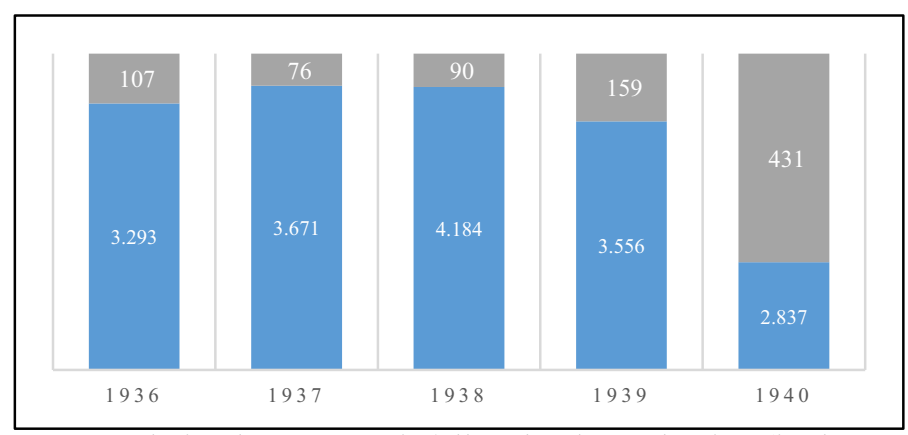

Figure 1. Correlation between Rainfall and Salt Production (in thousand tons)

Source: Compiled from Runtunuwu, E. dan Syahbuddin, H. [14] and Statistical Pocket Book of Indonesia 1941 [12].

In developing salt production, the Dutch colonial government paid attention to ecological conditions, especially the physical conditions of the sea, such as the texture and contours of the land and its geographical conditions. The choice of soil texture is very important to get optimal salt production. Soil texture suitable for salt production land is sandy clay with the composition read in the triangle above, which contains $50 \%$ sand, $20 \%$ dust, and $30 \%$ clay [3]. Soil textures like this can be found in the lands of the north coast of Java and Madura. The required land contours for salt ponds are flat over a vast stretch of land and 
are not expensive [15], while the contours for salt ponds should have a slope of not more than $2 \%$. This slope falls into the flat slope category [16]. The slope of this plot serves to drain seawater slowly to the following plot while optimizing the seawater evaporation process before entering the crystallization plot/table

In addition, the wind speed required for salt production is at least five $\mathrm{m} / \mathrm{sec}$, with air temperatures above 32o C during the day and a maximum humidity of 50\% [17]. During the Dutch colonial government, it was recorded that in 1904-1917 the average wind speed was above five $\mathrm{m} / \mathrm{sec}$, as in Figure 2 [12], [18].

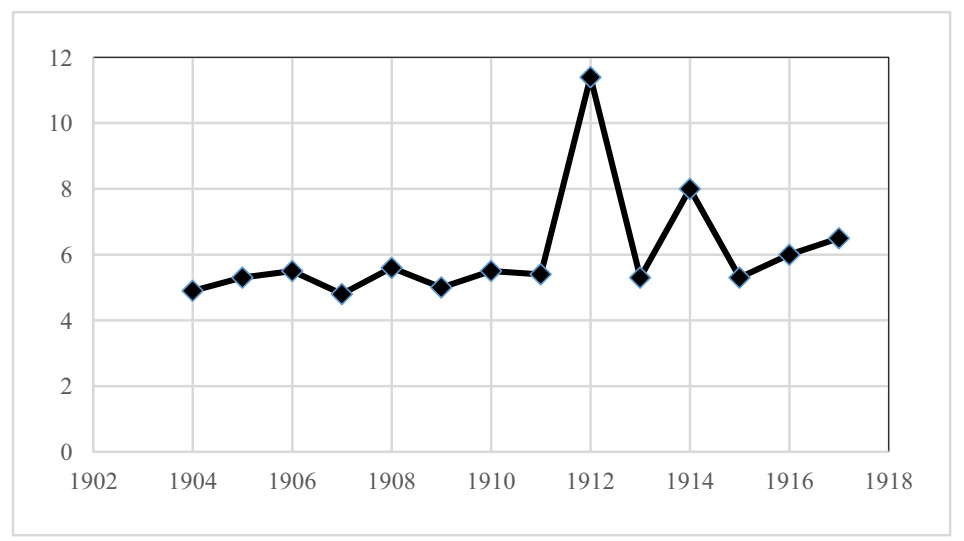

Figure 2. Speed of Wind during 1902-1918 (m/s)

Sources: Centraal Bureau voor de Statistiek.

In 1908-1917 it was also noted that the maximum daytime temperature was above 32o C. This shows that, in general the temperature in Indonesia is supportive for salt production, as shown in Table 2 .

Table 2. Temperature condition during 1908-1917

\begin{tabular}{|c|c|c|c|c|c|c|c|c|c|c|}
\hline \multirow{3}{*}{ 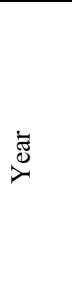 } & \multicolumn{2}{|c|}{$\begin{array}{c}\text { Average } \\
\text { Measurement }\end{array}$} & \multicolumn{4}{|c|}{ Cloud Coverage } & \multicolumn{4}{|c|}{ Temperature $\left({ }^{\circ} \mathrm{C}\right)$} \\
\hline & \multirow{2}{*}{ 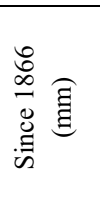 } & \multirow[b]{2}{*}{$\underset{\Xi}{\stackrel{\Xi}{\Xi}} \widehat{\Xi}$} & \multirow{2}{*}{ 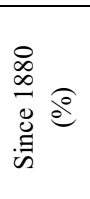 } & \multirow{2}{*}{ 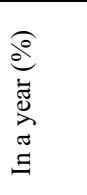 } & \multirow{2}{*}{ 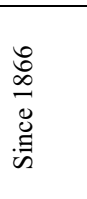 } & \multirow[b]{2}{*}{ 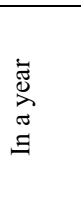 } & \multicolumn{2}{|c|}{ Max. } & \multicolumn{2}{|c|}{ Min. } \\
\hline & & & & & & & 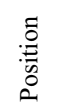 & صีّ & 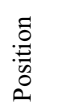 & 气ूँ \\
\hline 1908 & 758,76 & 758,60 & 59,2 & 67,2 & 26,04 & 26,22 & 33,0 & $5-12$ & 21,1 & $23-08$ \\
\hline 1909 & 758,75 & 758,39 & 59,6 & 72,1 & 26,04 & 26,18 & 33,5 & $11-09$ & 19,4 & $9-12$ \\
\hline 1910 & 758,74 & 758,11 & 60,0 & 71,7 & 26,05 & 26,21 & 34,3 & $7-11$ & 21,5 & $17-12$ \\
\hline 1911 & 758,74 & 758,94 & 60,1 & 65,8 & 26,06 & 26,29 & 33,7 & $18-09$ & 20,3 & $27-08$ \\
\hline 1912 & 758,75 & 758,94 & 60,0 & 56,0 & 26,06 & 26,51 & 34,7 & $22-09$ & 21,1 & $17-07$ \\
\hline 1913 & 758,75 & 758,98 & 59,9 & 55,9 & 26,07 & 26,44 & 33,0 & $25-11$ & 20,6 & $29-08$ \\
\hline
\end{tabular}




\begin{tabular}{|c|c|c|c|c|c|c|c|c|c|c|}
\hline 1914 & 758,76 & 759,34 & 59,6 & 50,3 & 26,08 & 26,65 & 35,0 & $28-09$ & 20,6 & $3 / 5-08$ \\
\hline 1915 & 758,76 & 758,86 & 59,6 & 61,1 & 26,09 & 26,70 & 33,1 & $\begin{array}{l}6-04 / \\
23-05\end{array}$ & 20,9 & $31-07$ \\
\hline 1916 & 758,75 & 758,12 & 59,8 & 66,8 & 26,09 & 26,22 & 33,5 & $18-10$ & 20,6 & $5-11$ \\
\hline 1917 & 758,74 & 758,27 & 60,2 & 72,0 & 26,09 & 26,00 & 32,9 & $18-11$ & 21,5 & $31-12$ \\
\hline
\end{tabular}

Source: Centraal Bureau voor de Statistiek [20]

According to Table 2, humidity dominantly happens in Indonesia. It is not very supportive of the salt production process. Humidity in 1940 was recorded to be above $50 \%$ on average [12], which made salt production not optimal, especially at its high-water content. This process also affects the content of other compounds that affect the purity of the salt, for example, the presence of magnesium sulphate [19]. This is because magnesium is one of the compounds that have hygroscopic (deliquescent) properties, which absorb water from the high humidity of the air.

\section{Conclusion}

The mapping of salt production centres by the Dutch colonial government considered ecological conditions, including rainfall, soil texture, land contours and access to seawater sources. Other factors include wind speed, air temperature, humidity and also the duration of the sun. In Indonesia, suitable locations for salt production are the northern part of Java, Madura Island, Nusa Tenggara and Sulawesi. Other regions are not suitable to be used as a salt pond for the evaporation system because they do not meet the requirements mentioned above.

\section{Acknowledgement}

This research and publication are funded by Ministry of Education Republic of Indonesia 2021 under the scheme of Research for Doctoral Dissertation No. 225-09/UN7.6.1/PP/2021.

\section{References}

[1] G. Alvao, A Treatise on the Moluccas (c. 1544), Probably the Preliminary Version of Antonio Galvao's Lost Historia das Molucas. Rome: Jesuit Historical Institute, (1971).

[2] A. Reid, Southeast Asia in the Age of Commerce, Vol. I: The lands below the winds. New Haven: Yale University Press, (1988).

[3] M. Z. Mahasin, Y. Rochwulalningsih, and S. T. Sulistiyono, "Coastal Ecosystem as Salt Production Centre in Indonesia," vol. 202, (2020), https://www.e3sconferences.org/articles/e3sconf/abs/2020/62/e3sconf_icenis2020_07042/e3sconf_ic enis2020_07042.html

[4] D. H. Patel, Recovery of Useful Chemicals From Seawater. Ahmedabad: Udgam School for Children, without year.

[5] C. Geertz, Agricultural Involution. University of California Press, 2020. Accessed: May 29, 2021. [Online]. Available: https://www.degruyter.com/document/doi/10.1525/9780520341821/html 
[6] A. A. Yani et al., "Environmental and social policy analysis on traditional salt production in Jeneponto Regency, Indonesia," IOP Conf. Ser. Earth Environ. Sci., vol. 343, p. 012091, Nov. (2019), doi: 10.1088/1755-1315/343/1/012091.

[7] Wisnu, S. Alrianingrum, Artono, and C. Liana, "Salt briquette: The form of salt monopoly in madura, 1883-1911," in Journal of Physics: Conference Series, Feb. (2018), vol. 953, no. 1, pp. 012181-012181. doi: 10.1088/1742-6596/953/1/012181.

[8] F. S. Chapin, "4.01 - Overview of Ecosystem Functions and Services: Their Importance and Vulnerability," in Climate Vulnerability, R. A. Pielke, Ed. Oxford: Academic Press, (2013), pp. 3-11. doi: 10.1016/B978-0-12-384703-4.00401-9.

[9] S. Dressel, G. Ericsson, and C. Sandström, "Mapping social-ecological systems to understand the challenges underlying wildlife management," Environ. Sci. Policy, vol. 84, pp. 105-112, Jun. (2018), doi: 10.1016/j.envsci.2018.03.007.

[10] I. Alenazi, "Salinity Gradient Solar Ponds: Theoretical Modelling and Integration with Desalination," Faculty of Engineering and Physical Sciences University of Surrey, Guildford, (2012).

[11] Kuntowijoyo, Perubahan Sosial Dalam Masyarakat Agraris Madura, 1850-1940. Yogyakarta: IRCISoD, (2002).

[12] BPS, Statistical Pocket Book of Indonesia 1941: With Comparative Date For 1940 or Earlier. (1942).

[13] DBNL, "Johannes van den Bosch, Nederlandsche bezittingen in Azia, Amerika en Afrika · dbnl," DBNL. https://www.dbnl.org/tekst/bosc036nede01_01/colofon.php (accessed May 29, 2021).

[14] E. Runtunuwu and D. H. Syahbuddin, "Perubahan Pola Curah Hujan dan Dampaknya Terhadap Periode Masa Tanam," vol. 26, pp. 1-12, (2007).

[15] L. A. Burston, "Application of A Salinity-Gradient Solar Pond in A Salt Affected Area of Victoria," The Royal Melbourne Institute of Technology, Victoria, (1996).

[16] M. Efendy, R. F. Sidik, and F. F. Muhsoni, "Pemetaan Potensi Pengembangan Lahan Tambak Garam di Pesisir Utara Kabupaten Pamekasan," J. Kelaut. Indones. J. Mar. Sci. Technol., vol. 7, no. 1, Art. no. 1, Apr. 2014, doi: 10.21107/jk.v7i1.791.

[17] M. Zaainuri, M. Efendy, F. F. Muchsoni, Hafiluddin, A. Budianto, and M. Syaiful, Pemetaan Lahan Garam di Jawa Timur. Bangkalan: UTMPress, (2020).

[18] Centraal Bureau voor de Statistiek, Jaarcijfers voor het Koninkrijk der Nederlanden Kolonien 1906. 'S-Gravenhage, (1908).

[19] T. S. Raffles, The History of Java, translatted version. Yogyakarta: Penerbit Narasi, (2014).

[20] Centraal Bureau voor de Statistiek, Jaarcijfers voor het Koninkrijk der Nederlanden Kolonien 1916. 'S-Gravenhage, (1919). 